\title{
Can bomb-test swapping cement US - Soviet relationships?
}

\section{Washington}

AN unusual Soviet proposal that the United States and the Soviet Union explode nuclear weapons at each other's test sites has added a new element to the complex negotiations surrounding a test ban treaty. The tests would allow precise calibration of the seismic networks that monitor nuclear blasts. US arms negotiation officials will only describe the new proposals as "interesting"

The inability to monitor accurately nuclear tests has been a major stumbling block in moving towards a nuclear test ban and a source of international tension. The US has repeatedly accused the Soviet Union of violating the 1974 treaty limiting underground tests to a yield of less than 150 kilotons. To circumvent monitoring uncertainties a private US group, the Natural Resources Defense Council (NRDC), last year took the remarkable step of setting up a seismic network inside the Soviet Union, with the cooperation of Soviet scientists. They believed they could show that seismic monitoring really worked. But this development was not welcomed by the United States, which continues to insist that a quite different monitoring technique, continuous reflectometry for radius versus time (CORRTEX) is the only really accurate way to measure the power of nuclear explosions.

CORRTEX is a very much more intrusive monitoring system as it requires a cable to be installed in a borehole drilled just fifty feet from the bomb test chamber. To monitor tests teams of US technicians would have to spend months at Soviet test sites and vice versa: so far the Soviets have opposed the proposal and insisted that seismic monitoring can be adequate. US experts are themselves divided over which technique is best.

Political rather than seismological issues may prompt US insistence on CORRTEX techniques, for the Reagan administration has shown no enthusiasm for a test ban. Continuing nuclear tests are essential to develop the X-ray lasers and other weapons required for the Strategic Defense Initiative (see p.815). And recently nuclear tests have been claimed as necessary to assess the reliability of the nuclear stockpile. According to the US Arms Control and Disarmament Agency, the first priority is reducing the number of nuclear weapons. "If you stop testing you lose reliability and credibility. That leads to a loss of confidence", said an official. This mirrors President Reagan's faith in negotiating from a position of strength.

There is continuing pressure on the Reagan administration to move towards a test ban. On Friday two provisions were introduced into the House of Representatives that would ban all tests more powerful than one kiloton. Similar legislation was introduced last year and only withdrawn to give Reagan greater freedom of action at his Iceland summit meeting with Soviet Premier Mikhail Gorbachev.

If bomb tests were exchanged both nations would have accurate seismic records of an explosion of known yield. Details of the swap will now be discussed at the meeting of the Nuclear Testing Experts Group at Geneva in early May. But it is thought likely that the US will continue to insist on the CORRTEX techniques that the Soviet Union has so far rejected.

Alun Anderson

- The Soviet Union has been using underground nuclear explosions for "economic purposes". Peaceful nuclear explosions (PNEs) were at one time advocated for major civil engineering schemes (such as the diversion of rivers) by both US and Soviet experts. The United States, however, soon dropped the idea and since the late 1970s the Soviet Union has said nothing further about using PNEs. On 19 April, however, the Soviet official news agency TASS reported that two underground PNEs of less than 20 ktonnes had been detonated in the area of Perm, and that these had "nothing in common" with the weapon tests two days earlier at the Seminpalatinsk test site. On 21 April, the daily Sovetskaya Rossiya explained that the Perm explosions had been intended to improve oil recovery by bringing together a series of "mini-formations" by creating a system of fissures. No ecological harm had been done by the explosion, the paper stressed.

\section{Moscow and Bonn agree to cooperate on nuclear power}

\section{Munich}

WEST Germany and the Soviet Union have agreed to cooperate on both the scientific and safety aspects of nuclear power. West German Research and Technology Minister Heinz Riesenhuber and the Chairman of the Soviet State Committee for the Utilization of Nuclear Energy, Andronik Petrosyants, signed a five-year pact to this effect in Moscow on 22 April.

The pact, along with agreements on health and agricultural cooperation, brings into operation a 'framework' agreement on scientific and technical cooperation between the two countries that was signed in July 1986. West German Health Minister Rita Süssmuth and her Soviet counterpart Evgenii Chasov signed the health agreement, which provides for the exchange of physicians and medical researchers, on 23 April in Moscow. The agreement on agricultural research is expected to be signed in Bonn during the first half of May.

The details of the nuclear agreement are to be worked out later on this year, reported a speaker at the West German Research Ministry (BMFT). The BMFT's draft protocol includes plans for cooperation on gas-, water- and sodiumcooled reactors, nuclear fusion and materials research as well as research into treatment of radioactive waste.

The pact also provides for industrial cooperation from the German side. West Germany's leading producer of nuclear power plants, Kraftwerk Union (KWU), is eager to sell service contracts to Soviet plants. Unlike the scientific exchange, which is to be supported financially by both sides, these contracts are to be paid for by the Soviets in the form of cash or goods, said KWU spokesman Wolfgang Breyer. "KWU can play a significant role" in increasing the standards of safety in Soviet power plants, said Breyer, "assuming that the Soviet Union wants our help."

The German-Soviet agreement reflects the significant warming of relations between the two countries in 1987. But it also promises to provide useful scientific information to both sides. "We want to see what the Soviets have learned from running sodium-cooled reactors over long periods," said Gerhard Heusener of the German Nuclear Research Centre in Karlsruhe. Heusener explained that the Soviets use sodium-cooled reactors like the BN350 to provide energy for desalinization plants, which in turn provide drinking water, and therefore the Soviets need a high level of reliability.

The negotiations leading up to the new agreement had been plagued with difficulties. For years, discussion foundered on the status of West German research institutions in West Berlin. As the Soviets refuse to recognize the right of such institutions to be situated in Berlin, still officially administered by the four victorious powers in the Second World War, such researchers can only be listed by name in the pact, without their respective institutions. This so-called ad personam solution was reached in 1984 .

The news of the nuclear agreement was accompanied by Soviet Nuclear Energy Minister Nikolai Lukonin's announcement on 22 April in Moscow that the Soviets plan to increase threefold the amount of electricity produced by nuclear power by 1995 .

Steven Dickman 